IZA DP No. 9008

Is Self-employment a Way to Escape from Skill Mismatches?

Judit Albiol Sanchez

Luis Diaz-Serrano

Mercedes Teruel

April 2015 


\title{
Is Self-employment a Way to Escape from Skill Mismatches?
}

\author{
Judit Albiol Sanchez \\ CREIP, Universitat Rovira $i$ Virgili \\ Luis Diaz-Serrano \\ CREIP, Universitat Rovira i Virgili \\ and IZA \\ Mercedes Teruel \\ CREIP, Universitat Rovira i Virgili
}

Discussion Paper No. 9008

April 2015

IZA

P.O. Box 7240
53072 Bonn
Germany

Phone: +49-228-3894-0

Fax: +49-228-3894-180

E-mail: iza@iza.org

\begin{abstract}
Any opinions expressed here are those of the author(s) and not those of IZA. Research published in this series may include views on policy, but the institute itself takes no institutional policy positions. The IZA research network is committed to the IZA Guiding Principles of Research Integrity.

The Institute for the Study of Labor (IZA) in Bonn is a local and virtual international research center and a place of communication between science, politics and business. IZA is an independent nonprofit organization supported by Deutsche Post Foundation. The center is associated with the University of Bonn and offers a stimulating research environment through its international network, workshops and conferences, data service, project support, research visits and doctoral program. IZA engages in (i) original and internationally competitive research in all fields of labor economics, (ii) development of policy concepts, and (iii) dissemination of research results and concepts to the interested public.
\end{abstract}

IZA Discussion Papers often represent preliminary work and are circulated to encourage discussion. Citation of such a paper should account for its provisional character. A revised version may be available directly from the author. 
IZA Discussion Paper No. 9008

April 2015

\section{ABSTRACT}

\section{Is Self-employment a Way to Escape from Skill Mismatches?}

During the last two decades, skill mismatches have become one of the most important issues of policy concern in the EU (European Commission, 2008). Hence, the literature has stressed the necessity to reduce skill mismatches. We contribute to this literature by analyzing the impact of the transition from salaried employment to self-employment on self-reported skill mismatches. To do so, we resort to the European Community Household Panel (ECHP) covering the period 1994-2001. Using panel data, we track individuals over time and measure their self-reported skill mismatch before and after the transition. Our empirical findings indicate not only that the average self-employee is less likely to declare being skillmismatched but also that those individuals who transit from salaried employment to selfemployment reduce their probability of skill mismatches after the transition.

JEL Classification: L26, J24, B23

Keywords: $\quad$ self-employment, skill mismatches, salaried employment

Corresponding author:

Luis Diaz-Serrano

Universitat Rovira i Virgili

Department of Economics

Av. Universitat, 1

43204 Reus

Spain

E-mail: luis.diaz@urv.cat 


\section{Introduction}

With global competition increasing, demographic change unfolding and rapid technological change intensifying, skill mismatches have come to the forefront of Europe's policy debate (Cedefop, 2010). Skill mismatches have important negative consequences for labor activity. For instance, skill mismatches have a negative impact on salaries, employment, competitiveness and economic growth, as well as on psychological aspects such as job satisfaction. Berlingieri and Erdsiek (2012) argue that being mismatched, from employees' perspective, could reduce their motivation and effort, leading to a lower level of productivity. This affects social interaction and generates significant economic and social costs (Allen et al., 2001). Hence, matching skills and available jobs through better labor market information and efficient job placement services should be a priority for policy-makers.

Most research regarding skill mismatches focuses on analyzing their determinants and their negative effects on society and more specifically on individuals. However, given that skill mismatches are one of the main challenges faced by governments, it is necessary to focus on how to overcome them. Keeping this in mind and given that most individuals who report being skill-mismatched are salaried employees (Allen et al., 2001; Vieira, 2005; Millán et al., 2013), we find it plausible that employees may overcome this problem by making the transition to selfemployment. To the best of our knowledge, an analysis of the impact of the transition from salaried employment to self-employment on the probability of reporting being skill-mismatched does not exist.

Given the relevance of matching skills and jobs and of promoting selfemployment, the aim of this paper is to determine whether those individuals who transit from salaried employment to self-employment report being less skillmismatched, both in the short and in the medium term. To this end, we resort to the 
European Community Household Panel (ECHP). This survey provides comparable micro data for a number of EU countries during the period 1994-2001. The panel nature of the data allows us to track individuals over time and measure their selfreported skill mismatch before and after the transition. Our results indicate that making the transition from salaried employment to self-employment significantly reduces the probability of reporting being skill-mismatched. This finding is robust to all our alternative models and specifications.

The remainder of the paper is structured as follows. Section 2 revises the findings in the literature. Section 3 describes the data and presents the descriptive statistics. Section 4 introduces the model and the econometric framework. Section 5 explains the main results and, finally, Section 6 draws conclusions from the analysis and offers some policy implications.

\section{Literature review}

A large part of the empirical literature gives support to the fact that self-employees are more satisfied than employees ${ }^{1}$ (Thompson et al., 1992; Blanchflower and Oswald, 1998; Blanchflower, 2000; Blanchflower et al., 2001; Hundley, 2001; Parasuraman and Simmers, 2001; Benz and Frey, 2004, 2008; Bradley and Roberts, 2004; Noorderhaven et al., 2004). From a theoretical point of view, self-employment transitions based on rational agent-based models assume that individuals will become self-employed if their expected utility from this option exceeds that associated with wage employment. Hence, the expected improvements in earnings from selfemployment in comparison with wages are one of the factors pointed out in the

\footnotetext{
${ }^{1}$ These results have been subject to some criticism. For instance, Blanchflower and Oswald (1998) state that job satisfaction levels might be subject to biases since self-employed people may be intrinsically more optimistic and cheerful than others. However, Frey and Benz's (2003) results show that job satisfaction increases when employees become self-employed even when they control for unobserved individual differences, such as the extent of cheerfulness or optimism.
} 
literature to explain the transition from salaried employment to self-employment (Rees and Shah, 1986; Fujii and Hawley, 1991; Taylor, 1996). However, other factors have attracted the attention of the empirical literature, while the role of earnings as a proxy for utility has been relaxed. According to some authors (Taylor, 1996; Blanchflower, 2000, 2004; Hamilton, 2000; Guerra and Patuelli, 2012), the nonpecuniary benefits of becoming self-employed justify the fact that individuals become and remain self-employed in spite of the fact that they may have lower initial earnings, lower earnings growth and higher income volatility with respect to salaried employment.

Different non-pecuniary determinants affect job satisfaction and may push individuals to become self-employed. In fact, it has been found that job satisfaction can be interpreted as an "excess" reward discounting future potential flows of utility deriving from a change in working conditions with respect to the current situation. Another simpler way of defining this would be that job satisfaction picks up the difference between the expected utility and the experienced utility in the workplace (Diaz-Serrano, 2009). The factors affecting job satisfaction are the following. First, the independence offered by self-employment may explain the transition from employment to self-employment (Evans and Leighton, 1989; Taylor, 1996; Hyytinen and Ruuskanen, 2006; van Praag and Versloot, 2007). In other words, self-employees may shape their own future (Hundley, 2001). Second, supervision and limited opportunities for promotion also arise as major determinants of job transition (Brockhaus, 1982). Third, emotional factors, such as feeling inappropriate or displaced, may push individuals to become self-employed (Shapero and Sokol, 1982). Furthermore, other feelings, such as feeling bored or angered, positively affect selfemployment choices (Wennekers et al., 2001; Hofstede et al., 2004). For instance, van Praag and Versloot (2007) point out that self-employees may be more satisfied because 
they enjoy more interesting jobs. This feeling may be more pronounced for individuals with higher education since they have more demanding jobs and have to meet higher expectations. Fourth, the risk of becoming unemployed may finally encourage potential self-employees to create their own company. Hence, all these factors increase the dissatisfaction of employees. Of course, the more dissatisfied employees are the ones who are expected to be more prone to enter self-employment (Brockhaus, 1980; Taylor, 1996; Blanchflower, 2000, 2004; Millán et al., 2013).²

Furthermore, there is a robust finding that skill mismatches are correlated with lower earnings (e.g. Borghans and de Grip, 2000; Groot and Maassen van den Brink, 2000; Chevalier, 2003; Cedefop, 2010). Consequently, skill mismatches appear as one of the most crucial factors affecting job satisfaction (Moshavi and Terborg, 2002; Cabral, 2005; Bender and Heywood, 2006; Lindley and McIntosh, 2008; McGuinness and Wooden, 2009; Verhaest and Omey, 2009; Mavromaras et al., 2010; Bender and Heywood, 2011; Mavromaras and McGuinness, 2012). For instance, Battu et al. (1997) concluded that job satisfaction is significantly adversely affected by mismatches. Belfield and Harris (2002) find only limited support for the argument that job matching explains greater job satisfaction. Johnson and Johnson (2002) report a negative relation between job satisfaction and perceived over-qualification in a longitudinal analysis. In fact, Allen and Velden (2001) and Allen and de Weert (2007) also point out that while educational mismatches may affect wages, skill mismatches are good predictors of job satisfaction and the on-the-job search.

One significant result in the literature is that skill mismatches are positively correlated with quitting and job turnover (e.g. Allen and Velden, 2001; Wolbers, 2003; Lee et al., 2011). For instance, Allen and Velden (2001) show that skill mismatches, in particular for employees declaring underutilization of skills, have a positive impact on

${ }^{2}$ Furthermore, previous evidence shows that switchers to entrepreneurship gain more satisfaction than switchers in the opposite direction (Frey and Benz, 2003). 
on-the-job search behavior. However, their study focuses on data from tertiary education in eleven European countries and Japan belonging to two different cohorts, those who graduated in the academic year 1990-91 and those who graduated in the academic year 1994-95. In a more recent study, Lee et al. (2011) analyze the determinants affecting intentions to become self-employed. Their results show that self-employment becomes desirable when there is a mismatch between the employees' innovation orientation and the characteristics of the organizations for which they work. Although they focus on the innovation orientation, their results highlight that the existence of a mismatch between the skills of an individual and those required in the work affects the intention to become self-employed positively. Conversely, some results show that individuals do not decide to become self-employed if they have skill shortages. For instance, Brixiova et al. (2009) develop a simple model of labor reallocation with transaction costs and show how skill shortages can inhibit firm creation and increase income inequality.

However, the literature also indicates other factors that may mitigate the advantages of self-employment, one of which is job security. It is argued that selfemployees have more limited employment protection than employees. In that sense, employees face a smaller gap between expected and actual job security. Self-employees may have more difficulties in predicting the extent of job security beforehand since the specific circumstances and challenges that they encounter in their business may change every year. As a consequence, self-employees experience much higher income volatility throughout their working lives, which in turn has a negative impact on the probability of becoming a homeowner (Diaz-Serrano, 2005). Furthermore, the pressure of work is higher among self-employees due to the inherent risk of businesses. In that sense, self-employees report that they find their work stressful, but they also 
state that they have control over their lives as well as being highly satisfied with their lives (Blanchflower, 2004; Guerra and Patuelli, 2012).

\section{Econometric model}

\subsection{Random effects vs. pooled probit model}

One of the most interesting features of our analysis is the use of longitudinal data. It allows us to study observed mobility from salaried employment to self-employment, rather than intentions to move, and its impact on the probability of reporting a skill mismatch. Our main outcome variable is $S M_{i t}$, a dummy that takes the value one if individual $i$ declares him- or herself to be skill-mismatched in period $t$ and zero otherwise. Hence, the econometric specification can be written as

$S M_{i t}=I\left(S M^{*}{ }_{i t}>0\right)=I\left(\lambda \operatorname{Trans}_{i t}+Z_{i t}^{\prime} \gamma+v_{i t}>0\right),(i=1, \ldots, N ; t=1, \ldots, T)$

where $I($.$) is a binary indicator function that takes the value one if the argument is true$ and zero otherwise, Trans $s_{i t}$ is an indicator picking up the transition from salaried employment to self-employment, $Z_{i t}$ is a vector of explanatory variables, $\lambda$ and $\gamma$ are a set of coefficients to be estimated and $v_{i t}$ is the error term. $\lambda$ is our parameter of interest since it shows the impact of the transition to self-employment on the skill mismatch.

Equation (3.1) represents the standard pooled probit model, which ignores the heterogeneity across individuals. If $v_{i t}$ is independent of $Z_{i t}^{\prime}$, the estimates produced by this model are consistent but might not be asymptotically efficient. However, the following clustering correction allows us to estimate the standard errors efficiently (Greene, 2004): 
$\hat{V}(\hat{\delta}, \hat{\gamma})=\left(\frac{N}{N-1}\right)\left(-H^{-1}\right)\left(\sum_{i=1}^{n} g_{i} g_{i}^{\prime}\right)\left(-H^{-1}\right)$

where $g_{i t}$ and $H$ are the gradient and the Hessian of the corresponding likelihood function of Equation (3.1), respectively, and $g_{i}=\sum_{t=1}^{T} g_{i t}$.

If we assume that the error term in Equation (3.1) can be additively decomposed into an unobservable individual-specific component, $\delta_{i}$, which is constant over time and normally distributed with zero mean and variance $\sigma_{\delta}^{2}$, and time-varying white noise, $e_{i t}$, independent of both $\delta_{i}$ and $Z_{i t}$, then Equation (3.1) becomes:

$$
\begin{aligned}
S M_{i t}= & I\left(S M^{*}{ }_{i t}>0\right)= \\
& =I\left(\lambda \text { Trans }_{i t}+Z_{i t}^{\prime} \gamma+\delta_{i}+e_{i t}>0\right), \quad(i=1, \ldots, N ; t=1, \ldots, T)
\end{aligned}
$$

Equation (3.3) corresponds to the standard random-effects probit model for which maximum likelihood estimates are generally consistent and asymptotically efficient (see e.g. Greene, 2000). We can also obtain an estimate of $\rho$ defined as:

$$
\rho=\operatorname{corr}\left(\delta_{i}+e_{i t}, \delta_{i}+e_{i s}\right)=\frac{\sigma_{\delta}^{2}}{\sigma_{\delta}^{2}+\delta_{e}^{2}}, \forall t \neq s
$$

This term is the correlation between the composite latent errors, $\delta_{i}+e_{i t}$, across any two time periods and it also measures the relative importance of the individual's unobserved effect, $\delta_{i}$.

So far, we know that both the pooled and the random-effects model provide consistent estimates under given circumstances. Moreover, after applying the correction expressed in Equation (3.1), the pooled probit model also turns out to be efficient. The estimated parameters of the correlated random-effects probit model will converge to the estimated parameters of the pooled probit model as $\rho$ tends to zero. In this setting, given the binary and panel nature of our data, a natural candidate to 
model skill mismatches is the random-effects probit model. As pointed out, a pooled bivariate probit model is also a feasible alternative.

\subsection{Endogeneity}

In the context of our research, one potential source of endogeneity stems from the fact that a number of unobserved factors might affect both the probability of being skillmismatched and the probability of being salaried and the transition to selfemployment. If we do not account for this endogeneity, the estimates will be inconsistent, thus generating an identification problem for the parameters in Equation (3.1). Given that both variables are binary and the pooled model is feasible in this setting, the pooled bivariate probit model, which simultaneously estimates Equation (3.1) and the transition equation defined below, is a good solution to account for endogeneity:

$\operatorname{Trans}_{i t}=I\left(\operatorname{Trans}^{*}{ }_{i t}>0\right)=I\left(X_{i t}^{\prime} \pi+\varepsilon_{i t}>0\right), \quad(i=1, \ldots, N ; t=1, \ldots, T)$

In Equation (3.5), Trans $_{i t}$ stands as defined in Equation (3.1), $X_{i t}$ is a vector of explanatory variables, $\pi$ is a set of coefficients to be estimated and $\varepsilon_{i t}$ is the error term. In this equation system, now $\rho^{*}=\operatorname{cov}\left(\varepsilon_{i t}, v_{i t}\right)$ is the correlation of the error terms in Equations (3.1) and (3.5). Endogeneity will exist if $\rho^{*}$ is sufficiently large. As we have already discussed in subsection 3.1, unbiased and asymptotically efficient estimates of the simultaneous equation model composed by Equations (3.1) and (3.5) can be obtained by means of the maximum likelihood estimation of a pooled bivariate probit model. Recall that since we estimate a pooled model, we do not account for individual- 
specific effects. However, as we explained in subsection 3.1, this should not be a problem after using the clustering correction defined in Equation (3.2). ${ }^{3}$

\section{Data and variables}

\subsection{Data and restricted samples}

The data used in this paper come from the European Household Panel (ECHP). The main advantage of this survey is that the questionnaires are standardized. Each year, all the surveyed individuals in the participating countries are asked the same questions; consequently, the information is directly comparable. Furthermore, it contains not only information at the household level, but also very detailed data at the individual level. These interviews cover a wide range of topics concerning living conditions. For instance, they include detailed information about the surveyed individuals' income, financial situation in a wider sense, working life, housing, social relations, health and sociodemographic information.

The data collection started in 1994 and was conducted over eight consecutive years. We make use of all the waves of the ECHP, thus covering the 1994-2001 period ${ }^{4}$ for eleven of the EU-15 countries (Denmark, the Netherlands, Belgium, France, Ireland, Italy, Greece, Spain, Portugal, Austria and Finland). For Austria and Finland, the available files only cover the periods $1995^{-2001}$ and 1996-2001, respectively.5

The purpose of this paper is to test whether self-employment is a way to escape from skill mismatches and whether workers perceive their job context differently when they become self-employed. Therefore, the panel structure of the ECHP allows us to

\footnotetext{
3 See Diaz-Serrano and Stoyanova (2010) for further discussion.

4 EU-15 refers to the fifteen member states of the European Union before the 1 May 2004 enlargement.

5 See Peracchi (2002) for a review of the organization of the survey.
} 
track individuals who participate in the survey in consecutive years and change their job status from salaried employment to self-employment during the sample period.

We restrict our sample to those individuals who are self-employees or salaried employees, aged 18-65, either males or females and working part-time or full-time. Individuals who do not participate in consecutive waves are excluded from our sample. Workers are counted as self-employees if they answer "yes" to a direct question on selfemployment $^{6}$ and salaried employees if they answer "yes" to a direct question on private employment ${ }^{7}$. Since we are interested in analyzing transitions from salaried employment to self-employment, individuals who remain in self-employment during the whole sample period are also excluded from the analysis.

Our final sample consists of a pool sample of countries containing 172,174 observations belonging to 46,830 individuals. This large sample is what we call the "full sample." In this sample, those individuals who remain salaried employees throughout the whole sample period are used as a control group for those who experience transitions from salaried employment to self-employment. Alternatively, from this "full sample," we create a subsample consisting of those individuals who switch only once from salaried employment to self-employment and remain in this employment regime until the end of the sample period. In this sample, we only consider individuals who experience the transition, so individuals are compared with themselves before and after the transition. We refer to this as the "restricted sample" and it consists of 4,414 observations belonging to 922 individuals.

\footnotetext{
${ }^{6}$ Individuals are forced to choose only one main occupation, either working for an employer in paid employment or working in self-employment. Since no information is collected on secondary activities, it is not possible to determine whether some individuals combine both self-employment and paid employment.

7 We exclude workers in the public sector from the analysis because the determinants of occupational choice and job satisfaction among public sector workers deviate from those of private (salaried employment) sector workers. This difference is related to several factors, such as a relatively smaller workload for public sector workers and a motivation to serve the community (Francois, 2000; Glazer, 2004; Besley and Ghatak, 2005; Prendergast, 2007; Delfgaauw and Dur, 2008, 2009; Millán et al., 2013).
} 


\subsection{Variables}

Table A1 in the annex contains the description of the variables used in this analysis. The variable Job Satisfaction originally ranged from one to six, with one referring to individuals who are not satisfied with their job and six referring to those who are completely satisfied with their work. This variable is collapsed into a dummy variable that takes a value equal to one when the variable is equal to five or six and zero for values equal to four or less. ${ }^{8}$

Our main outcome variable, that is, self-reported Skill Mismatch, is a dummy variable obtained from the elicited responses to the following question: "Do you feel that you have the skills or qualifications to do a more demanding job than the one you now have?" Those individuals who respond affirmatively to this question are considered to be skill-mismatched.

To test our hypothesis, we create different transition variables. The consideration of different transition variables will help us to determine the robustness of our analysis. From the "full sample," we construct two transition variables named Transition 1 and Transition 2. Transition 1 is a dummy variable that takes the value one when individual $i$ is in salaried employment in period $t-1$ and in self-employment in periods $t, t+1$ and so on until the end of the sample period and zero if the individual is in salaried employment at $t-1$ and $t$. Those individuals who become self-employed only temporarily are considered as missing values. Transition 2 is a dummy variable that takes the value one if individual $i$ transits from salaried employment to selfemployment between period $t-1$ and period $t$, regardless of whether he or she is selfemployed temporarily or until the end of the period, and zero if the individual is working in salaried employment. Note that the main difference between these two last

\footnotetext{
8 We choose this procedure because, in most cases, there are only a few observations for some of the satisfaction scales.
} 
transition variables is that in the first one, Transition 1, we compare those individuals who switch only once with those individuals working in salaried employment and in the second one, Transition 2, we compare all the individuals who switch at least once from salaried employment to self-employment with those individuals working in salaried employment.

From the "restricted sample," we construct the following transition variables: Transition Long Term, which is a dummy variable that takes the value one since the individual becomes self-employed until the end of the period in our sample and zero in the previous periods. This variable captures the long-term effect of the job transition on the skill mismatch. We also create a variable named Transition Short-Term 1, which is a dummy variable that takes the value one if individual $i$ switches to selfemployment between period $t-1$ and period $t$ and zero otherwise. This variable is equal to one only in the period in which the individual make the transition and zero afterwards. This variable captures the short-term effect. Analogously, we also create two more transition variables, one named Transition Short-Term 2, which is a dummy variable that takes the value one only in the second year after the transition, and another named Transition Short-Term 3-7, which takes the value one from the third to the last year of the sample period after the transition and zero otherwise. These three variables allow us to capture the potential existence of adaptation effects, in terms of skills, on self-employment.

Our vector of explanatory variables accounts for various determinants: a set of individual-specific variables, such as demographic indicators (Age and Female), educational attainment (Educ2 and Educ3), family aspects (Family Size) and employment characteristics (Tenure, Log Hours Worked and Permanent Contract).

Table 1 reports some of the descriptive information of the variables in the model. The summary statistics are reported separately for the "full" and the "restricted 
sample," and for the latter, we report the summary statistics for those in salaried employment "before switching" and those in self-employment "after switching." Column (1) reports the descriptive statistics for the "full sample." Here, we have all the individuals who switch from salaried employment to self-employment, both those who switch only once and those who switch at least once. The percentage of individuals who switch once in comparison with those in salaried employment is $0.52 \%$, while the percentage of individuals who make the transition at least once in comparison with those individuals in salaried employment is $1.46 \%$. Here, the numbers indicate that our sample is formed mostly by individuals who perform more than one transition. As dependent variables, we have Job Satisfaction and Skill Mismatch. Recall that our satisfaction variable is a binary indicator. We observe that $48.43 \%$ of individuals report being satisfied with their current job status. The percentage of individuals who report being skill-mismatched is $52.76 \%$. We observe that the average age is almost 37 years and most of the individuals are males. Furthermore, the percentage of individuals with tertiary education is $\mathbf{1 6 . 5 0} \%$, while individuals with secondary education account for more than $35 \%$. The average family size is 3 members. Regarding the employment characteristics variables, the average number of years in employment is 7 and the logarithm of the hours worked is more than 3. Concerning firm-specific indicators, the occupation with the highest value is craft and trade workers and the highest value of the main activity is recorded for the service sector, with $20.43 \%$ and $51.26 \%$, respectively.

Column (2) reports the descriptive statistics for the "restricted sample." As we mentioned before, of the 46,830 individuals participating in the "full sample," only 922 make the transition from salaried employment to self-employment and remain there until the end of the sample period. The average percentage of individuals who report being skill-mismatched, accounting for those individuals who switch to self- 
employment, is $47.12 \%$. In general, these switchers seem to be similar in terms of age and education relative to those in the "full sample," though the share of females is lower. The average number of years in the current job is 6 , almost 1 year less than in the "full sample." The natural logarithm of the hours worked per week is slightly higher, 3.84. Almost 33\% of the switchers declare that they had a permanent contract in the previous year. The craft and trade workers occupation accounts for the highest value, while around $36.66 \%$ of the main activity is accounted for by the industry sector. Column (3) and Column (4) report the descriptive statistics separately for the periods before switching (salaried employment) and the periods after switching (selfemployment). As one would expect, the average age after making the transition is higher than before, 39 years old. The percentage of females and the individuals with tertiary education have decreased to $15.68 \%$ and $15.47 \%$, respectively. We also find that on average, the total number of members of the household is 3 . However, the percentage of individuals with secondary education has increased to $35.29 \%$. Employment characteristics are on the same line as those before switching to selfemployment. Concerning firm-specific indicators, craft and trade workers and service sector continue to account for the higher values.

It is worth noting the interesting pattern of our key variable, Skill Mismatch. The summary statistics reveal differences among the individuals in the "full sample" and those in the "restricted sample." In particular, $52.76 \%$ of individuals declare themselves to be skill-mismatched in the "full sample," while this percentage decreases to $47.12 \%$ in the "restricted sample." The decrease in this percentage once individuals make the transition should be highlighted. The percentage of individuals who report being skill-mismatched decreases significantly from $54.08 \%$ before the switch to 43.38\% after the switch. Moreover, in Column (4), we observe that this value decreases through time. These results represent an interesting snapshot of the skill-mismatched 
individuals in the European Union and gives us the opportunity to see the variability among the individuals who switch at least once from salaried to self-employment and those who are in salaried employment.

----Insert Table 1 here----

Table 2 reports the share of individuals reporting being skill-mismatched before and after switching to self-employment by country. The base category consists of individuals working in salaried employment. At first glance, this figure reveals that our key variable is quite heterogeneous across the board, which allows us to look for the effects on both before and after switching. Before switching, the highest value is recorded for Finland, for which the percentage of individuals is $67.42 \%$, while in the Netherlands it is around $38 \%$. After switching, Belgium is the country with the highest presence of individuals reporting being skill-mismatched, more than 59\%, while Greece reports the lowest percentage. Furthermore, we observe that on average, for all the EU countries in our sample, the percentage of individuals who report being skillmismatched is lower after making the transition to self-employment than when they were in salaried employment. This supports the idea that self-employees report lower levels of skill mismatch in all countries in comparison with individuals working in salaried employment.

----Insert Table 2 here----

\section{Empirical results}

Table 3 contains the results of two alternative specifications. Model (1) presents the results of the univariate probit model regarding the probability of reporting job satisfaction. Model (2) shows the results of the univariate probit model regarding the 
probability of reporting being skill-mismatched. This model is merely used as an initial approach to determine the factors affecting self-reported skill mismatches and to detect potential differences between the workers in salaried employment and the selfemployed.

Our findings indicate that the probability of reporting job satisfaction for those individuals reporting being skill-mismatched in their current workplace is 4.4 percentage points lower than that for their skill-matched counterparts. It is important to remark that among all the individual characteristics variables considered in the equation, the skill-mismatch indicator is found to be the variable with the largest negative estimated marginal effects. Hence, skill mismatches appear to be one of the most crucial factors affecting job satisfaction. When distinguishing by employment status, self-employees are 6.1 percentage points more likely to report being satisfied and 8.7 percentage points less likely to report being skill-mismatched than salaried employees. Age is U-shaped for the probability of reporting job satisfaction and inverted U-shaped for the probability of reporting being skill-mismatched. Females are less satisfied than males, but they are less likely to report being skill-mismatched in their current work. As one might expect, more educated workers are more likely to report job satisfaction and to report being skill-mismatched. The logarithm of working hours per week has a statistical and positive effect on job satisfaction and family size has a statistical and negative effect on the skill-mismatch probability. Individuals who work in their current job as legislators, senior officials or managers are 6.2 percentage points more likely to report being satisfied and 3.9 percentage points less likely to report being skill-mismatched. Those in elementary occupations are less likely to report being job satisfied, while those who are skilled agricultural and fishery workers are less likely to report being skill-mismatched. 
Table 4 reports the marginal effects of the estimation of our empirical models relating to the determinants of the probability of reporting being skill-mismatched. To allow for comparisons, we report the marginal effects instead of the estimated coefficients. In these models, we use the same controls as in Model (2) in Table 3. The results regarding the determinants of the probability of self-reported skill mismatches are qualitatively the same as in Model (2) in Table 3. Therefore, in Table 4, we just focus on the estimated marginal effects for our variables of interest, that is, transitions from salaried to self-employment.9 In Models (3) to (6), we report the estimates of the single-equation models using the "full sample." In these models, we estimate the impact of the transition for those individuals who switch only once (Models (3) and (5)) and for those individuals who switch more than once (Models (4) and (6)). According to the estimates from the pooled probit model (Models (3) and (4)), on average, individuals who switch only once to self-employment are almost 10 percentage points less likely to report being skill-mismatched, while for those switching more than once, the marginal effect is of 8 percentage points. When we resort to the pooled probit model (Models (5) and (6)), we find that the corresponding decrease in the probability of being skill-mismatched is of 14 and 10 percentage points, respectively. We obtain large estimated marginal effects in both models, though it seems that in the pooled probit model the marginal effects are biased downwards.

Models (7) to (10) report the results for the "restricted sample," that is, for those individuals who switch from salaried to self-employment and remain selfemployed until the end of our sample period. In this sample, the individuals

9 The estimated coefficients of the control variables included in the models shown in Table 4, which are not reported, provide the same qualitative results as the coefficients reported in Table 3 in terms of the direction and the size of the effect. Full estimates of the models in the table are available from the authors upon request. 
experiencing this transition are compared with themselves before and after the transition. As in the previous models, we observe that the pooled and the randomeffects model both provide the same qualitative results. We consider this to be proof of robustness, since the two samples differ significantly in terms of size and composition. Our comments will focus on the marginal effects obtained from the random-effects model. As a general remark, we can say that the estimated effects from this "restricted sample" are slightly augmented with respect to the ones from the "full sample." In Model (9), we test for the long-term impact of switching from salaried to selfemployment on the probability of being skill-mismatched. The variable labeled Transition Long Term takes the value 1 from the period of the transition until the end of the sample period. Our estimates indicate that, on average, individuals are 15 percentage points less likely to report being skill-mismatched after experiencing the transition to self-employment. The impact of our variables picking up the short-term effect of the transitions (Transition Short Term 1 and Transition Short Term 2) is provided in Model (10). The estimated marginal effects for these variables are the same as in Model (9). That is, 1 year after the transition, the probability of reporting being skill-mismatched is about 15 percentage points smaller than in the years prior to the transition. This holds for the second, third and so on years after the transition. We find that both the short-term and the long-term impact of the transition are the same, which is quite an interesting result.

Finally, Model (11) estimates a bivariate probit model of the determinants of both the probability of reporting being skill-mismatched and the probability of experiencing the transition from salaried to self-employment for the "restricted sample." This model is intended to control for the potential endogeneity of the variable picking up the transition in the skill-mismatch equation. In the bivariate model, we use a variable that indicates whether the individual holds a permanent labor contract as an 
exclusion restriction. This variable is included in the transition equation but not in the skill-mismatch equation. The Wald statistics reported in Table 5 do not allow us to reject the null hypothesis that the error terms of the two equations are uncorrelated. Therefore, the presence of endogeneity is discarded. This indicates that the estimates from the single-equation models are consistent. In addition, since in the pooled models we apply the clustering correction proposed in Equation (3.2), these models are efficient.

----Insert Table 4 here----

\section{Summary and concluding remarks}

The recent increase in skill mismatches in Europe has attracted the attention of the academic community due to the effects on labor activity (salaries, employment and productivity), competitiveness and growth as well as on psychological aspects such as job satisfaction. Skill mismatches also affect social inclusion and generate significant economic and social costs (Allen and Velden, 2001). Hence, matching skills and available jobs through better labor market information and efficient job placement services should be a priority for policy-makers. In contrast to Lazear's (2005) assumptions, however, self-employees need more basic and specialized skills than salaried employees. In a more recent study, Lechmann and Schnabel (2014) find that self-employees perform more tasks than salaried employees and their work requires more skills. Moreover, there is a strong belief that self-employment fosters innovation and competitiveness. Recent studies suggest that self-employment has tangible positive economic impacts not only on salaried employment but also on per capita income growth and poverty reduction (Goetz et al., 2012). In this framework, it is 
important to investigate whether self-employment is a way to escape from skill mismatches.

Using panel data from eleven European countries covering the period 19942001, in this article, we have investigated the relationship between the transition from salaried to self-employment and the probability of reporting being skill-mismatched. This is one of the few studies based on panel data; therefore, we could observe whether individuals feel skill-mismatched before and after the transition. Our results indicate that switching from salaried to self-employment significantly reduces the probability of reporting being skill-mismatched in the short and the long term. To test the sensitiveness of this effect, we construct alternative transition variables and samples. We find that the negative impact of the transition to self-employment remains robust across alternative samples, specifications and models. We think this is proof of the robustness of our results, which suggest that self-employment is a way to escape from skill mismatches, and believe this to be a crucial policy issue, not only for policymakers but also for social partners and trade unions. As a result, policies aimed at promoting self-employment might be effective in reducing skill mismatches in the workforce, which in turn will have a positive impact on job satisfaction. Our finding supports the idea that mechanisms such as specific start-up programs should be emphasized. We think that an improved distribution of skills among the labor market through an increase in self-employment should raise the economic performance in Europe through the gains of competitiveness and productivity.

\section{Acknowledgments}

We acknowledge all the participants in the Research Seminar of Strategy \& Entrepreneurship program at Erasmus University (Rotterdam, November 2013), in the Research Seminar in Panteia/EIM (Zoetermeer, December 2013) and in the WIPE 
2014 PhD seminar (Universitat Rovira i Virgili, February 2014) and André Van Stel for providing us with helpful comments on earlier drafts. Financial support from the Regional Government of Catalonia (grant \#2014-SGR-1395) and from the Spanish Ministry of Economy and Competitiveness (grant \#ECO2010-20829) is also acknowledged. The usual disclaimer applies. 


\section{References}

Allen, J. and de Weert, E. (2007): "What Do Educational Mismatches Tell Us About Skill Mismatches? A Cross-country Analysis”, European Journal of Education, 42 (1): $59-73$.

Allen, J. and Velden, R. (2001): "Educational mismatches versus skill mismatches: effects on wages, job satisfaction, and on-the-job search", Oxford Economic Papers, 53(3): $434-452$.

Astebro, A. and Thompson, P. (2011): “Entrepreneurs, Jacks of all trades or Hobos?”, Research Policy, 40: 637-649.

Battu, H., Belfield, C. and Sloane, P. (1997): “Overeducation among graduates: a cohort view”, University of Aberdeen, Department of Economics, Mimeo.

Belfield, C. and Harris, R. (2002): "How well do theories of job matching explain variations in job satisfaction across education levels? Evidence for UK graduates”, Applied Economics, 34(5): 535-548.

Bender, K. and Heywood, J. (2006): "Job satisfaction of the highly educated: The role of gender, academic Tenure, and earnings", Scottish Journal of Political Economy, 53(2): 253-279.

Bender, K. and Heywood, J. (2011): "Educational mismatch and the careers of scientists”, Education Economics, 19(3): 253-274.

Benz, M. and Frey, B. (2003): "The value of autonomy: Evidence from the selfemployed in 23 countries”, University of Zurich, Working Paper \#173, Zurich, Switzerland.

Benz, M. and Frey, B. (2004): "Being independent raises happiness at work", Swedish Economic Policy Review, 11: 95-134.

Benz, M. and Frey, B. (2008): "Being independent is a great thing: Subjective evaluations of self-employment and hierarchy", Economica, 75(298): 362-383. 
Berlingieri, F. and Erdsiek, D. (2012): "How relevant is job mismatch for German graduates?”, ZEW-Centre for European Economic Research, Discussion Paper, (12075).

Besley, T. and Ghatak, M. (2005): “Competition and incentives with motivated agents", American Economic Review, 95(3): 616-636.

Blanchflower, D. (2000): "Self-employment in OECD countries”, Labour Economics, 7: $471-505$.

Blanchflower, D. (2004): "Self-employment: More may not be better", Swedish Economic Policy Review, 11(2): 15-74.

Blanchflower, D. and Freeman, R. (1997): “The Attitudinal Legacy of Communist Labor Relations", Industrial and Labor Relations Review, 50: 4438-459.

Blanchflower, D. and Oswald, A. (1998): “What makes an entrepreneur?”, Journal of Labor Economics, 16(1): 26-60.

Blanchflower, D., Oswald, A. and Stutzer, A. (2001): "Latent entrepreneurship across nations”, European Economic Review, 45(4-6): 680-691.

Borghans, L. and de Grip, A. (Eds.). (2000): "The overeducated worker?: the economics of skill utilization” Edward Elgar Publishing.

Bradley, D. , and Roberts, J. (2004): "Self-Employment and job satisfaction: Investigating the role of Self-Efficacy, depression, and seniority”, Journal of Small Business Management, 42(1): 37-58.

Brixiova, Z., Li, W. and Yousef, T. (2009): "Skill shortages and labor market outcomes in Central Europe”, Economic Systems, 33(1): 45-59.

Brockhaus, R. (1980): "Risk taking propensity of entrepreneurs", Academy of Management Journal, 23(3): 509-520.

Brokhaus, R. (1982): “The Psychology of Entrepreneur in C. Kent, DL Sexton and KH Vesper”, Encyclopedia of Entrepreneurship. Englewood Clifs. 
Cabral, J. (2005): "Skill mismatches and job satisfaction", Economics Letters, 89(1): $39-47$

Cedefop (2010): “The skill matching challenge”, Briefing Note, Thessaloniki. Available at: http://www.cedefop.europa.eu/EN/Files/3056_en.pdf

Chevalier, A. (2003): “Measuring over-education”, Economica, 70(279): 509-531.

Delfgaauw, J. and Dur, R. (2008): "Incentives and workers motivation in the public sector” Economic Journal, 118: 171-191.

Delfgaauw, J. and Dur, R. (2009): "From public monopsony to competitive market: More efficiency but higher prices”, Oxford Economic Papers, 61(3): 586-602.

Diaz-Serrano, L. and Stoyanova, A. (2010): "Mobility and housing satisfaction: an empirical analysis for 12 EU countries”, Journal of Economic Geography,10(5): 661683.

Diaz-Serrano, L. (2005): "On the Negative Relationship between Labor Income Uncertainty and Homeownership: Risk Aversion vs. Credit Constraints”, Journal of Housing Economics 14, 109-126.

Diaz-Serrano, L. (2009): "Disentangling the Housing Satisfaction Puzzle: Does Homeownership Really Matter?”, Journal of Economic Psychology 30(5), 745-755.

European Commission (2008, November): The Bordeaux communiqué on enhanced European cooperation in vocational education and training. InCommuniqué of the European Ministers for vocational education and training, the European social partners and the European Commission, meeting in Bordeaux on 26 November 2008 to review the priorities and strategies of the Copenhagen process.

Evans, D. and Leighton, L. (1989): "Some Empirical Aspects of Entrepreneurship", American Economic Review, 79(3): 519-535.

Francois, P. (2000): "Public service motivation as an argument for government provision”, Journal of Public Economics, 78(3): 275-299. 
Frey, B. , and Benz, M. (2003): "Being independent is a great thing: Subjective evaluations of self-employment and hierarchy" CESifo Working Paper No. 959.

Fujii, E. , and Hawley, C. (1991):”Empirical aspects of self-employment”, Economics Letters, 36(3): 323-329.

Glazer, A. (2004): "Motivating devoted workers”, International Journal of Industrial Organization, 22(3): 427-440.

Goetz, S., Fleming, D. and Rupasingha, A. (2012): "The Economic Impacts of SelfEmployment”, Journal of Agricultural and Applied Economics, 44(3): 315-321

Greene, W. (2004): “Convenient estimators for the panel probit model: Further results”, Empirical Economics, 29: 21-47.

Greene, W. H. (2000): “Econometric Analysis”, 4th ed. New Jersey: Prentice Hall.

Groot, W. and Maassen Van Den Brink, H. (2000):"Overeducation in the labor market: a meta-analysis”, Economics of Education Review, 19(2): 149-158.

Guerra, G. and Patuelli, R. (2012): "The role of job satisfaction in transitions into selfemployment”, Quaderni DSE Working Paper n. 849.

Hamilton, B. (2000): "Does entrepreneurship pay? An empirical analysis of the returns to self-employment”, Journal of Political Economy, 108(3): 604-631.

Hofstede, G., Noorderhaven, N., Thurik, A., Uhlaner, L., Wennekers, A. and Wildeman, R. (2004): "Culture's role in entrepreneurship: self-employment out of dissatisfaction. Innovation, entrepreneurship and culture: The interaction between technology, progress and economic growth", 162-203.

Hundley, G. (2001): "Why and when are the self-employed more satisfied with their work?”, Industrial Relations, 40(2): 293-316.

Hyytinen, A. and Ruuskanen, O. (2006): "What makes an entrepreneur independent? Evidence from time use survey", (No. 1029), The Research Institute of the Finnish Economy. 
Johnson, G. and Johnson, W. (2002): "Perceived over-qualification and dimensions of job satisfaction: a longitudinal analysis", Journal of Psychology, 134: 537-555.

Lazear, E.P. (2005): “Entrepreneurship”, Journal of Labor Economics, 23(4): 649-680.

Lechmann, D. , and Schnabel, C. (2014): “Are the self-employed really jacks-of-alltrades? Testing the assumptions and implications of Lazear's theory of entrepreneurship with German data” Small Business Economics, 42(1): 59-76.

Lee, L., Wong, P., Foo, M. and Leung, A. (2011): "Entrepreneurial intentions: The influence of organizational and individual factors”, Journal of Business Venturing, 26: $124-136$

Lee, S. , Lim, S. , and Pathak, R. (2011): "Culture and entrepreneurial orientation: a multi-country study", International Entrepreneurship and Management Journal, 7(1): 1-15.

Lindley J. and McIntosh S.(2008):"A Panel Analysis of the Incidence and Impact of Overeducation”, Department of Economics, University of Sheffield, July

Mavromaras, K. and McGuinness, S. (2012): "Overskilling dynamics and education pathways", Economics of Education Review, 31(5): 619-628.

Mavromaras, K., McGuinness, S., O'leary, N., Sloane, P. and Fok, Y. (2010): “The problem of overskilling in Australia and Britain”, The Manchester School,78(3): 219-241.

McGuinness, S. and Wooden, M. (2009): "Overskilling, job insecurity, and career mobility”, Industrial Relations: A Journal of Economy and Society, 48(2): 265-286.

Millán, A., Millán, J., Román, C. and van Stel, A. (2013): "How does employment protection legislation influence hiring and firing decisions by the smallest firms?”, Economic Letters, 121(3): 444-448.

Millan, J., Hessels, J., Thurik, R. and Aguado, R. (2013): "Determinants of job satisfaction: A European comparison of self-employed and paid employees”, Small Business Economics, 40(3): 651-670. 
Moshavi, D. and Terborg, J. (2002): "The job satisfaction and performance of contingent and regular customer service representatives: A human capital perspective", International Journal of Service Industry Management, 13(4): 333347.

Noorderhaven, N., Thurik, A., Wennekers, A. and van Stel, A. (2004): "The role of dissatisfaction and per capita income in explaining self-employment across 15 European countries", Entrepreneurship Theory and Practice, 28(5): 447-466.

Parasuraman, S. and Simmers, C. (2001): "Type of employment, work-family conflict and well-being: a comparative study", Journal of Organizational Behavior, 22(5): 551-568.

Peracchi, F. (2002): “The European community household panel: a review”, Empirical Economics 27: 63-90.

Prendergast, C. (2007): “The motivation and bias of bureaucrats”, American Economic Review, 97(1): 180-196.

Rees, H. and Shah, A. (1986): "An Empirical Analysis of Self-Employment in the UK", Journal of Applied Econometrics, 1(1): 95-108.

Shapero, A. and Sokol, L. (1982): “The social dimensions of entrepreneurship", Encyclopedia of entrepreneurship, 72-90.

Taylor, M. (1996): “Earnings, Independence or Unemployment: Why Become Selfemployed?”, Oxford Bulletin of Economics and Statistics 58(2): 253-265.

Taylor, M. (2004): "Self-employment in Britain: when, who and why?", Swedish Economic Policy Review, 11(2): 141-173.

Thompson, C. , Kopelman, R. , and Schriesheim, C. (1992): "Putting all one's eggs in the same basket: A comparison of commitment and satisfaction among self-and organizationally employed men”, Journal of Applied Psychology,77(5): 738.

Van Praag, M. and Versloot, P. (2007): "What is the value of entrepreneurship? A review of recent research”, Small Business Economics, 29: 351-382. 
Verhaest, D. and Omey, E. (2009): “Objective over-education and worker well-being: A shadow price approach”, Journal of Economic Psychology, 30(3): 469-481.

Vieira, J. (2005): "Skill mismatches and job satisfaction", Economics Letters, 89: 3947.

Wennekers, A., Noorderhaven, N., Hofstede, G. and Thurik, A. (2001): "Cultural and economic determinants of business ownership across countries”, in W.D. Bygrave et al. (eds), Frontiers of Entrepreneurship Research 2001, Wellesley, MA: Babson College, 179-90.

Wolbers, M. (2003): “Job Mismatches and their Labour-Market Effects among SchoolLeavers in Europe”, European Sociological Review, 19(3): 249-266. 


\begin{tabular}{|c|c|c|c|c|}
\hline & & All & Before switching & After switching \\
\hline \multicolumn{5}{|l|}{ Sample } \\
\hline Number of observations & 172174 & 4414 & 1544 & 2870 \\
\hline Number of individuals & 46830 & 922 & 922 & 922 \\
\hline \multicolumn{5}{|l|}{ Dependent variables } \\
\hline Job Satisfaction & $48.43 \%$ & & & \\
\hline Skill Mismatch & $52.76 \%$ & $47.12 \%$ & $54.08 \%$ & $43.38 \%$ \\
\hline \multicolumn{5}{|l|}{ Explanatory variables } \\
\hline \multicolumn{5}{|l|}{ Restricted sample } \\
\hline Transition long term & & $65.02 \%$ & & \\
\hline Transition short term 1 & & $20.00 \%$ & & $30.76 \%$ \\
\hline Transition short term 2 & & $15.06 \%$ & & $23.17 \%$ \\
\hline Transition short term3_7 & & $29.95 \%$ & & $46.06 \%$ \\
\hline \multicolumn{5}{|l|}{ Full sample } \\
\hline Transition 1 & $0.52 \%$ & & & \\
\hline Transition 2 & $1.46 \%$ & & & \\
\hline \multicolumn{5}{|l|}{ Demographic characteristics } \\
\hline Age & 36.96 & $37 \cdot 72$ & 35.26 & 39.04 \\
\hline Female & $37.49 \%$ & $16.45 \%$ & $17.87 \%$ & $15.68 \%$ \\
\hline \multicolumn{5}{|l|}{ Education } \\
\hline Educ2 & $35 \cdot 54 \%$ & $34.89 \%$ & $34.13 \%$ & $35.29 \%$ \\
\hline Educ3 & $16.50 \%$ & $15 \cdot 72 \%$ & $16.19 \%$ & $15.47 \%$ \\
\hline \multicolumn{5}{|l|}{ Family aspects } \\
\hline Family Size & 3.48 & 3.59 & $3 \cdot 56$ & $3 \cdot 56$ \\
\hline \multicolumn{5}{|l|}{ Employment characteristics } \\
\hline Selfemp & $1.47 \%$ & $65.02 \%$ & & \\
\hline Tenure & $7 \cdot 39$ & 6.07 & 7.58 & 7.12 \\
\hline Log Hours Worked & 3.67 & 3.84 & 3.75 & 3.76 \\
\hline Lagged Permanent Contract & & $32.98 \%$ & $60.75 \%$ & $60.15 \%$ \\
\hline \multicolumn{5}{|l|}{ Firm specific indicators } \\
\hline \multicolumn{5}{|l|}{ Occupations } \\
\hline Services & $5.71 \%$ & $15 \cdot 52 \%$ & $7.57 \%$ & $7.68 \%$ \\
\hline Professionals & $6.89 \%$ & $8.09 \%$ & $7.44 \%$ & $7.88 \%$ \\
\hline Technicians & $12.58 \%$ & $11.17 \%$ & $12.43 \%$ & $12.14 \%$ \\
\hline Clerks & $14.71 \%$ & $3.42 \%$ & $7.19 \%$ & $7.27 \%$ \\
\hline Service_workers_and_salers & $13.08 \%$ & $12.57 \%$ & $14.89 \%$ & $15.11 \%$ \\
\hline Agricultural_and_fishery_workers & $1.81 \%$ & $8.27 \%$ & $3.49 \%$ & $3.57 \%$ \\
\hline Craft_and_trade_workers & $20.43 \%$ & $26.55 \%$ & $26.16 \%$ & $25.91 \%$ \\
\hline Plant_and_machine_operators & $11.91 \%$ & $7.41 \%$ & $9.58 \%$ & $9.34 \%$ \\
\hline Elementary_occupations & $11.20 \%$ & $5.89 \%$ & $9.71 \%$ & $9.70 \%$ \\
\hline \multicolumn{5}{|l|}{ Main Activity } \\
\hline Agricultural Sector & $3.45 \%$ & $10.04 \%$ & $5.69 \%$ & $6.25 \%$ \\
\hline Manufacturing Sector & $41.14 \%$ & $36.66 \%$ & $44.62 \%$ & $43.95 \%$ \\
\hline Service Sector & $51.26 \%$ & $5.08 \%$ & $47.86 \%$ & $47.93 \%$ \\
\hline
\end{tabular}


Table 2. Sample statistics of skill mismatched switchers (full sample)

\begin{tabular}{lcccc}
\hline & & \multicolumn{2}{c}{$\begin{array}{c}\text { \% of individuals reporting being skill } \\
\text { mismatched }\end{array}$} \\
\hline & Observations & Individuals & Before switch & After switch \\
\hline Denmark & 10,033 & 2,463 & 62.87 & 45.00 \\
Netherlands & 20,840 & 5,331 & 38.33 & 29.63 \\
Belgium & 8,244 & 2,413 & 64.97 & 59.15 \\
France & 22,325 & 5,589 & 53.02 & 21.82 \\
Ireland & 12,442 & 4,085 & 53.35 & 49.09 \\
Italy & 21,144 & 5,479 & 50.11 & 43.90 \\
Greece & $\mathbf{1 1 , 0 3 4}$ & $\mathbf{3 , 2 5 7}$ & $\mathbf{5 8 . 9 4}$ & $\mathbf{0 5 . 0 0}$ \\
Spain & $\mathbf{2 2 , 5 4 0}$ & 6,622 & 55.32 & 46.02 \\
Portugal & 23,148 & 5,506 & 44.17 & 42.48 \\
Austria & $\mathbf{1 1 , 5 0 8}$ & 3,115 & 61.78 & 52.75 \\
Finland & 8,916 & 2,970 & 67.42 & 56.15 \\
\hline Sound &
\end{tabular}

Source: Own elaboration from the ECHP 
Table 3. Estimates of job satisfaction and the skill mismatch equation

$\begin{array}{ll}\frac{\text { Model (1) }}{\text { Probit }} & \text { Model (2) } \\ \text { Job Satisfaction } & \text { Skill Mismatch }\end{array}$

Skill Mismatch

Self-employment $t_{t}$

Age $_{t}$

Age 2t

Female $_{t}$

Educ3t

Educ2 $_{\mathrm{t}}$

Tenure $_{t}$

Tenure $2_{t}$

Log Hours Worked

Family Size $_{t}$

Permanent Contract Co 1

Services

Professionals

Technicians

Clerks

Service_workers_and_salers

Agricultural_and_fishery_workers

Craft_and_related_trade_workers

Plant_and_machine_operators

Elementary_occupations

Agricultural Sector

Manufacturing Sector

Service Sector

Constant

Sample size

Notes:

1. *** Significant at $1 \%,{ }^{* *}$ Significant at 5\%, ${ }^{*}$ Significant at $10 \%$.

2. All models include dummy for years and countries.

3. Numbers in parenthesis are the coefficient standard errors.
$-0.044^{* * *}$

$0.061^{* * *}$

(0.015)

$-0.011^{* * *}$

(0.002)

$0.000^{* * *}$

(0.000)

$-0.030^{* * *}$

(0.007)

$0.051^{* * *}$

(0.009)

$0.033^{* * *}$

(0.006)

$-0.000$

(0.001)

0.000

(0.000)

$0.021^{* *}$

(0.013)

$-0.002$

(0.002)

$-0.087^{* * *}$

(0.015)

$0.009^{* * *}$

(0.002)

$-0.000^{* * *}$

(0.000)

$-0.082^{* * *}$

(0.007)

$0.184^{* * *}$

(0.009)

$0.122^{* * *}$

(0.007)

$-0.000$

(0.002)

$-0.000^{*}$

(0.000)

$-0.014$

(0.013)

$-0.006^{* * *}$

(0.002)

$\begin{array}{cc}0.062^{* * *} & -0.039^{* *} \\ (0.018) & (0.018) \\ 0.058^{* * *} & -0.018 \\ (0.018) & (0.019) \\ 0.035^{* *} & -0.006 \\ (0.017) & (0.017) \\ -0.012 & 0.024 \\ (0.017) & (0.017) \\ -0.030^{*} & 0.017 \\ (0.018) & (0.018) \\ -0.053^{*} & -0.087^{* *} \\ (0.030) & (0.030) \\ -0.070^{* * *} & -0.071^{* * *} \\ (0.016) & (0.017) \\ -0.076^{* * *} & -0.050^{* *} \\ (0.017) & (0.017) \\ -0.125^{* * *} & -0.026 \\ (0.017) & (0.018) \\ -0.013 & -0.034 \\ (0.023) & (0.024) \\ -0.016 & 0.006 \\ (0.012) & (0.014) \\ 0.012 & 0.025^{*} \\ (0.012) & (0.013) \\ & \end{array}$

81754

82998 
Table 4. Estimates of the skill mismatch equation

\begin{tabular}{|c|c|c|c|c|c|c|c|c|c|c|}
\hline & \multicolumn{4}{|c|}{ Full sample } & \multicolumn{4}{|c|}{ Restricted sample } & \multirow{3}{*}{\multicolumn{2}{|c|}{$\begin{array}{l}\text { Bivariate probit } \\
\text { Restricted sample } \\
\text { Model (11) }\end{array}$}} \\
\hline & \multicolumn{2}{|c|}{ Pooled probit } & \multicolumn{2}{|c|}{ Random effects probit } & \multicolumn{2}{|c|}{ Pooled probit } & \multicolumn{2}{|c|}{ Random effects probit } & & \\
\hline & Model (3) I & Model (4) & Model (5) & Model (6) & Model (7) & Model (8) & Model (9) & Model (10) & & \\
\hline & $\begin{array}{c}\text { Skill } \\
\text { Mismatch } \\
\end{array}$ & $\begin{array}{c}\text { Skill } \\
\text { Mismatch } \\
\end{array}$ & $\begin{array}{c}\text { Skill } \\
\text { Mismatch } \\
\end{array}$ & $\begin{array}{c}\text { Skill } \\
\text { Mismatch } \\
\end{array}$ & $\begin{array}{c}\text { Skill } \\
\text { Mismatch }\end{array}$ & $\begin{array}{c}\text { Skill } \\
\text { Mismatch } \\
\end{array}$ & $\begin{array}{c}\text { Skill } \\
\text { Mismatch }\end{array}$ & $\begin{array}{c}\text { Skill } \\
\text { Mismatch } \\
\end{array}$ & $\begin{array}{c}\text { Skill } \\
\text { Mismatch } \\
\end{array}$ & $\begin{array}{l}\text { Transition } \\
\text { long term }\end{array}$ \\
\hline Transition long term $t$ & & & & & $\begin{array}{c}-0.118^{* * *} \\
(0.029)\end{array}$ & & $\begin{array}{c}-0.152^{* * *} \\
(0.032)\end{array}$ & & $\begin{array}{l}-0.081^{*} \\
(0.131)\end{array}$ & \\
\hline Transition short term $1_{t}$ & & & & & & $\begin{array}{c}-0.115^{* * *} \\
(0.028)\end{array}$ & & $\begin{array}{c}-0.149 * * * \\
(0.033)\end{array}$ & & \\
\hline Transition short term $2 \mathrm{t}$ & & & & & & $\begin{array}{c}-0.115^{* * *} \\
(0.031)\end{array}$ & & $\begin{array}{c}-0.148^{* * *} \\
(0.037)\end{array}$ & & \\
\hline Transition short term 3_7t & & & & & & $\begin{array}{c}-0.119^{* * *} \\
(0.037)\end{array}$ & & $\begin{array}{c}-0.151^{* * * *} \\
(0.043)\end{array}$ & & \\
\hline Transition $1 \mathrm{t}$ & $\begin{array}{c}-0.098^{* * * *} \\
(0.017)\end{array}$ & & $\begin{array}{c}-0.144^{* * *} \\
(0.024)\end{array}$ & & & $\begin{array}{c}-0.144^{* * *} \\
(0.024)\end{array}$ & & & & \\
\hline Transition $2 \mathrm{t}$ & & $\begin{array}{c}-0.081^{* * *} \\
(0.011)\end{array}$ & & $\begin{array}{c}-0.107^{* * *} \\
(0.015)\end{array}$ & & & & & & \\
\hline Rho & & & 0.661 & 0.659 & & & 0.544 & 0.544 & & -0.068 \\
\hline LR-test of $\rho=0$ & & & $3.6 \cdot 10^{4}$ & $3.7 \cdot 10^{4}$ & & & 650.31 & 650.29 & & \\
\hline (p-value) & & & 0.000 & 0.000 & & & 0.000 & 0.000 & & \\
\hline Pseudo-R² (pooled) & 0.058 & 0.058 & & & 0.074 & 0.074 & & & & \\
\hline Wald chi ${ }^{2}$ & 5292 & 5368 & & & 201.71 & 202.24 & & & & \\
\hline Prob>chi2 & 0.000 & 0.000 & & & 0.000 & 0.000 & & & & \\
\hline Wald test of $\rho=0$ ) & & & & & & & & & & 0.918 \\
\hline (p-value) & & & & & & & & & & 0.337 \\
\hline Sample size & 170536 & 172174 & 170536 & 172174 & 4414 & 4414 & 4414 & 4414 & 4414 & 4414 \\
\hline
\end{tabular}

1. ${ }^{* * *}$ Significant at $1 \%,{ }^{* *}$ Significant at $5 \%,{ }^{*}$ Significant at $10 \%$.

2. All models include dummy for years and countries.

3. Numbers in parenthesis are the coefficient standard errors.

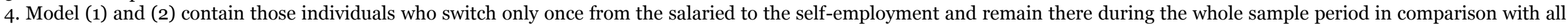
the individuals

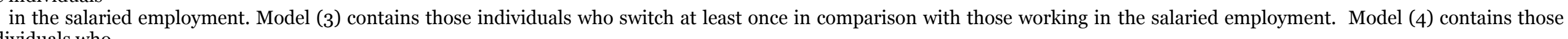
individuals who

switch only once in comparison with those in the salaried employment. 


\section{Annex of tables}

Table A1. Definition of the variables used in the econometric estimates

Variable

Dependent variables

Job Satisfaction

Skill Mismatch

Explanatory variables

Restricted sample

Transition long term

Transition short term 1

Transition short term 2

Transition short term 3-7

Full sample

Transition 1

Transition 2

Demographic characteristics

Age

Age2

Female

Education

Educ2

Educ3

Family aspects

Family size

Employment characteristics

Self-employment

Tenure

Tenure2

Log Hours Worked

Permanent contract

Firm specific indicators

Occupations

Services
Description

Dummy that takes the value 1 if the individual is satisfied with its work or main activity and o for unsatisfied individuals.

Dummy that takes the value 1 if the individual reports being skill mismatched and o otherwise.

Dummy that takes the value 1 since the period in which the individual changes the job status and o for the previous periods. Dummy that takes the value 1 in the period in which the individual changes job status and o otherwise.

Dummy that takes the value 1 in the second period in which the individual has changed job status and o otherwise.

Dummy that takes the value 1 from the third period to the seventh in which the individual has changed job status.

Dummy that takes the value 1 in the period in which the individual changes job status and o for those working in the salaried employment. Those individuals that become selfemployees temporally are not considered, hence, the variable is a missing.

Dummy that takes the value 1 in the period in which the individual becomes a self-employee and o for those working in the salaried employment, regardless the number of periods they stay as a self-employees.

Age of the individual.

Age of the individual squared.

Dummy that takes the value 1 if the individual is a woman.

Dummy that takes the value 1 if the highest educational level of the individual is secondary education.

Dummy that takes the value 1 if the highest educational level of the individual is tertiary education.

Number of persons in the household.

Dummy that takes the value 1 if the individual works as selfemployee and o for those working in the salaried employment.

Total of years in the current job.

Total of years in the current job squared.

Natural logarithm of hours working per week.

Dummy that takes the value 1 if the individual had a permanent contract in the previous year.

Dummy that takes the value 1 if the occupation in current job is legislators, senior officials and managers. 
Professionals

Technicians

Clerks

Service_workers_and_salers

Agricultural_and_fishery_workers

Craft_and_trade_workers

Plant_and_machine_operators

Elementary_occupations

Main activity

Agricultural Sector

Manufacturing Sector

Service Sector
Dummy that takes the value 1 if the occupation in current job is professionals.

Dummy that takes the value 1 if the occupation in current job is technicians and associate professionals.

Dummy that takes the value 1 if the occupation in current job is clerks.

Dummy that takes the value 1 if the occupation in current job is service workers and shop and market sales workers.

Dummy that takes the value 1 if the occupation in current job is skilled agricultural and fishery workers.

Dummy that takes the value 1 if the occupation in current job is craft and related trades workers.

Dummy that takes the value 1 if the occupation in current job is plant and machine operators and assemblers.

Dummy that takes the value 1 if the main occupation in current job is elementary occupations.

Dummy that takes the value 1 if the main activity in the current job is agriculture.

Dummy that takes the value 1 if the main activity in the current job is manufacturing sectors.

Dummy that takes the value 1 if the main activity in the current job is service sectors.

Country dummies

Dummies equal 1 for individuals living in the named country, and o otherwise. The following countries are

included: Austria, Belgium, Denmark, Finland, France, Greece, Ireland, Italy, Netherlands, Portugal and Spain.

Source: Own elaboration from the ECHP 